\title{
Antifungal Potency of Aframomum melegueta (Alligator Pepper) Seed Extracts on Postharvest Rot Fungi of Two Citrus Species
}

\author{
H.O. Bamidele \\ University of Ilorin, Department of Crop protection, Faculty of Agriculture, University of Ilorin, Kwara \\ State, Nigeria \\ helenbamidele007@gmail.com
}

Keywords: Antifungal potency, Aframomum melegueta, postharvest fungi, extracts, Citrus species

\begin{abstract}
This study was carried out to test the potency of both aqueous and ethanolic extracts of small and large Aframomum melegueta (alligator pepper) on the control of postharvest deterioration of lime (Citrus aurantifolia) and lemon (Citrus limonum) caused mostly by Aspergillus niger, Trichothecium roseum, Rhizoctonia species, Alternaria tenuis, Absidia ramose and Rhizopus stolonifer which were isolated from the fruits of lime and lemon. The fungal isolated were tested for its ability to cause the same disease condition in a healthy Citrus (C. limonum and C. aurantifolia). The extracts were concentrated at different range from $5-30 \mathrm{mg} / \mathrm{ml}$. The study showed that the extracts of Aframomum melegueta were able to suppress fungi growth on Citrus aurantifolia and Citrus limonum. All the concentrations of the ethanolic extract of small A. melegueta were potent to all the organisms. The small seed ethanolic extracts were most effective on Rhizopus stolonifer while larege seed ethanolic extracts were most effective on Alternaria tenuis which recorded the highest zone of inhibition. It is recommended that $5 \mathrm{mg} / \mathrm{ml}$ concentration which has the highest zone of inhibition of the extract can be used as spray in controlling the postharvest deterioration of the citrus fruits. Therefore, they will serve as a good natural seed fungicide (protectant) against Citrus in storage.
\end{abstract}

\section{Introduction}

Aframomum melegueta is a tropical herbaceous perennial plant of genus Aframomum belonging to the family Zingiberaceae (ginger family). For ages, alligator pepper has been used in traditional medicine for the treatment of many diseases. Grains of Paradise, A. melegueta (Alligator pepper) has been elucidated using larvae of the Egyptian cotton leaf worm, Spodoptera littoralis (Boisduval) (Lepidoptera: Noctuidae). Leaf portions treated with either hexane or methanol fruit extracts showed strong dose-dependent antifeedant activities [1]. Similarly, the hexane, methanol and most importantly water extracts of $A$. melegueta deterred feeding in third instars of one of the worldwide most important pests of cruiciferous crops, the diamond back moth Plutella xylostella L. (Lepidoptera: Yponomeutidae) in laboratory bioassays [2] (Ntonifor et al., 2010). Furthermore, the methanol and water extracts of the plant also caused at least $80 \%$ mortality of second instars of the pest [2].

The extracts of the seeds have been used for years in the treatment of infectious diseases as well as in treating wounds and prevention of infections [3]. Phytochemical analysis revealed the presence of alkaloids, glycosides, tannins, flavonoids, sterols, triterpenes, and oils, while the methanolic fraction contains alkaloids, glycosides, tannins, flavonoids, sterols, and resins [4]. The pungent, peppery taste of the seeds is caused by aromatic ketones [5] such as (6)-paradol; essential oils occur only in traces. It is a plant with both medicinal and nutritive values, found commonly in rain forest. The phytochemicals obtained from the seed of Aframomum melegueta have been used for years in the treatment of infectious diseases [6]. The grains of $A$. melegueta possess active ingredients that may be exploited for local development of antimicrobials [7].

Extracts from the seed of Aframomum melegueta have potent antiseptic or bactericidal properties and have been used in treating wounds and preventions of infections [3]. According to [8], A. melegueta was tested for antimicrobial effects on five pathogenic bacteria: Bacillus cereus; Staphylococcus aureus; Escherictaia coli; Salmonella typhi; and Klebsiella pneumonia and was able 
to inhibit the growth of Klebsiella pneumonia and Salmonella typhi. The findings revealed that extract from Aframomum melegueta contain phytochemicals which offer an enormous potential as bio control of these pathogens and source of antimicrobial agents of therapeutic importance [9]. Water and ethanol leaf extracts of the plant separately was active against the soft rot causing fungi, Aspergillus niger and Fusarium oxysporum and also significantly reduced the growth of Botryodiploidia theobromae mycelium on yam tubers [10]. Each of the water and ethanol peppery seed extracts of the plant was used to reduce post-harvest deterioration of cassava caused by $A$. niger, Fusarium solani and B. theobromae [11].

Aqueous and ethanol extracts of A. melegueta similarly prevented the growth of $B$. theobromae, A. niger, A. flavus, Mucor sp., Rhizopus stolonifer, Penicillium sp. and Fusarium sp. isolated from deteriorating okro [12]. Similarly, A. melegueta seed powders were found to be effective in reducing the microbial contents of tomato ketchup and minced meat under laboratory conditions [13]. [6], also showed that they have antimicrobial and antifungal effects and also are effective against schistosomes. The antimicrobial activities of A. melegueta have been attributed to its essential oils, gingerol, shagaol and paradol among other constituents [6]. Meanwhile, [6] stated that considering that Aframomum melegueta is rich in such phytochemical constituents such as flavonoids, it explains its inclusion in many herbal remedies for protection against allergies, inflammation, platelet aggregation, ulcers, toxins that affect the liver and tumours.

Citrus is a flowering plants in the family Rutaceae which is believed to have originated in the part of Southeast Asia bordered by Northeastern India, Myanmar (Burma) and the Yunnan province of China. The world production of Citrus is greater than that of any other fruit crop [14]. Citrus was introduced to Nigeria by the Federal Department of Agriculture and Missionaries in the 1930s [15]. Subsequently, it spread throughout the country and is currently rated as the most widely planted fruit tree in Nigeria. In Nigeria the major Citrus producing state are Benue, Taraba, Oyo, Imo, Ebonyi, Kogi, Kaduna, Ogun, Ondo, Ekiti, Edo, Delta and Osun [14].

Citrus fruits are beneficial to health and contribute to the prevention of degenerative process, particularly lowering incidence and mortality rate of cancer and cardio- and cerebro-vascular diseases [16]. The protection of Citrus fruits provide against these diseases has been attributed to the various antioxidant phytonutrients contained in Citrus spices [17], [16].

Citrus is an important nutritive and welfare food that needs to be taken all the time. The production is seasonal and highly difficult to prepare. Even the production during the rainy season is faced with the problem of pest and diseases. It would be advantageous for the spoilage of the fruits to be checkmated with plant materials that are environmental friendly, with no residual effects. This would help to circumvent or minimise the high cost and potential hazards of the chemicals, farmers need to resort to more creative, easily affordable and sustainable pest management methods to combat pest problems so as to sustain or increase yields and ensure food security.

The aim of this study was to test the potency of seed extracts of Aframomum melegueta against postharvest rot fungi isolated from two citrus fruits.

\section{Materials and Methods}

\section{Sources of materials}

Fresh citrus fruits such as lemon (C. limonum) and lime (C. aurantifolia) were bought inYoruba road market, Ilorin, Kwara State. Fresh small and large seeded Aframomum melegueta (Alligator pepper) were bought from Oja Oba market Ilorin, Kwara State. The experiment was carried out in the Microbiology laboratory, University of Ilorin, Ilorin Kwara State.

\section{Sterilization of materials}

Citrus fruits were thoroughly washed with distilled water, allowed to dry and surfaced sterilized with $70 \%$ ethanol for 1 minute [9]. 


\section{Isolation of fungal pathogens of Citrus fruits)}

To isolate the rot pathogens responsible for the postharvest deterioration of Citrus fruits, a modified method of [9] was used. 10g of Potato Dextrose Agar (PDA) was dissolved in $250 \mathrm{ml}$ of distilled water and amended with $1 \%$ streptomycin (to suppress bacterial growth) in a conical flask. The medium was plugged with cotton wool, wrapped with aluminum foil and autoclaved at $121^{\circ} \mathrm{C}$ for 15 minutes, allowed to cool before dispensing into sterile Petri dishes. To isolate the rot pathogens of the citrus fruits, cut sections ( 3 or $4 \mathrm{~mm}$ ) from the rotted margins were cut out with a sterile scalpel and inoculated on the PDA and incubated at room temperature $\left(28 \pm 1^{\circ} \mathrm{C}\right)$ for 7 days and observed for fungal growth. The organisms were then sub-cultured on freshly prepared PDA plates to obtain pure culture of the isolates.

\section{Identification of fungal isolates}

The pure cultures of the isolates were used for identification. Identification was carried out using macroscopic (structural features of growing colonies on plates) and microscopic examination. For the microscopic examination, slide mounts of the isolates was prepared using Lactophenol cotton blue dye and observed under the microscope. The isolates observed were compared with those on Standard Fungi Manuals of [18].

\section{Pathogenicity tests}

To ascertain the pathogenicity of the fungal isolates, healthy citrus $(C$. aurantifolia and $C$. limonum) fruits obtained were first washed with distilled water, allowed to dry and surface sterilized with $70 \%$ ethanol. With the aid of a sterile $5 \mathrm{~mm}$ cork borer, three to four disc were punched out on each fruit and a seven day old culture of each isolate was inoculated into the fruits and sealed with transparent tape. The fruits were then incubated for 10 days and observed for symptoms. On establishment of symptoms, infected parts were cultured on freshly prepared PDA and the pure cultures identified as the previously isolated and identified organisms. This was taken as evidence that the organisms were pathogenic on the citrus fruits.

\section{Preparation of seed extracts}

The two varieties of Aframomum melegueta (large and small) were removed from the pod separately and then kept in different labeled polyethylene bags. They were later ground separately into a uniform powder using blender. Each of the powder of both the large and small varieties of Aframomium melegueta were then stored in air tight aluminum foil inside the refrigerator for chemical analysis.

\section{Extraction of Aframomum melegueta}

The extraction was done using soaking method of [9]. The ground samples were extracted using distilled water and ethanol solvent. About $100 \mathrm{~g}$ of the powdered samples were extracted with $1000 \mathrm{ml}$ of distilled water while $100 \mathrm{~g}$ of each samples was extracted with $1000 \mathrm{ml}$ of $70 \%$ ethanol. Each mixture was shaken vigorously and allowed to stand for twenty four hours. It was then filtered through Whatman No.6 filter paper. The filterates were poured into separate conical flasks plugged with cotton and heated on Bunsen burner for about $5 \mathrm{~min}$ to avoid contamination [19]. The filterates were then poured into test-tubes before evaporating them to dryness over a water bath at low temperature $\left(40^{\circ} \mathrm{C}\right)$ until a desirable extract was gotten.

\section{Determination of the yield of extract}

About $100 \mathrm{~g}$ of $A$. melegueta was soaked in $100 \mathrm{ml}$ of the extracting solvent (distilled water and ethanol) and allowed to stand for three hours. It was shaken and filtered. The filtrate was put in a weighed evaporation dish and evaporated to dryness. The dish and extract were weighed after cooling in desiccators. The yield of the extracts were determined by using [20] formula.

$$
\text { Concentration yield }=\mathrm{C}_{1} \mathrm{~V}_{1}=\mathrm{C}_{2} \mathrm{~V}_{2}
$$


where $\mathrm{C}_{1}=$ Known concentration mentioned above, $\mathrm{V}_{1}=$ Volume in mili litre $(1 \mathrm{ml}), \mathrm{C}_{2}=$ Unknown concentration, $\mathrm{V}_{2}=$ Volume in mililitre $(1000 \mathrm{ml})$.

\section{Antifungal potency of seed extracts of $A$. melegueta}

To determine how sensitive each pathogen isolate was to the two seeds of A. melegueta (small and large) extracts. The pure cultures of the isolates were then incubated at room temperature for $72 \mathrm{~h}$. They were then inoculated on sterile Potato Dextrose Agar (PDA) plates containing streptomycin. The extracts were then reconstituted in minimal $(1 \mathrm{ml})$ of sterile distilled water. Those extracts were poured into sterile plates and allowed to solidify. A swab sterile stick was used to level the surface of the extracts in the plates. $5 \mathrm{~mm}$ sterile cork borer was flamed and allowed to cool for a minute so as to reduce hotness and were used to perforate or create holes of the swabbed solidify extracts inside the plates. The seven holes were then filled with different concentrations. $500 \mathrm{mg}$, $1000 \mathrm{mg}, 1500 \mathrm{mg}, 2500 \mathrm{mg}$, and $3000 \mathrm{mg}$ of powder/granules in $100 \mathrm{ml}$ of distilled water which gave the concentration of $5 \mathrm{mg} / \mathrm{ml}, 10 \mathrm{mg} / \mathrm{ml}, 15 \mathrm{mg} / \mathrm{ml}, 20 \mathrm{mg} / \mathrm{ml}, 25 \mathrm{mg} / \mathrm{ml}, 30 \mathrm{mg} / \mathrm{ml}$ and control of the extracts respectively. The control experiment was without any plant extract but only with sterile distilled water and ethanol. Each was labelled appropriately.

The petridishes were inoculated and left for $1 \mathrm{~h}$ at room temperature for the extracts to diffuse before growth commenced. The plates were incubated at room temperature for $72 \mathrm{~h}$ after which the result were taken by measuring the diameters of the zones of inhibition around the perforated areas with the aid of metric ruler and were recorded accordingly. The effects of the extracts on fungal isolates were compared with those of the standard antifungal agents.

\section{Determination of Minimum Inhibition Concentration (MIC)}

The Minimum Inhibitory Concentration of each extract was determined using the method of [21], [22]. The MIC was taken as the least concentration that will prevent fungal growth.

\section{Results}

\section{Identified fungal pathogens}

Different fungi were successfully isolated from both Citrus aurantifolia and Citrus limonum, with the use of taxonomic and morphology references. The pathogens identified were Aspergillus niger, Trichothecium roseum, Rhizoctonia species, Alternaria tenuis, Absidia ramose and Rhizopus stolonifer, all of which were implicated as pathogens when tested on nine different fruits each of healthy Citrus aurentifolia and Citrus limonum. Of all the isolated fungi, A. niger and T. roseum had the highest percentage frequency of occurrence compare to Rhizopus stolonifer.

\section{Pathogenicity tests}

Fungal growth was first observed in Citrus limonum plates after four days and fifteen days after plating in Citrus aurantifolia plates. The fungal growths observed in lemon and lime were compared with the healthy ones (Plates 1and 2). Further observation showed that Citrus aurantifolia fungal growth was restricted for fifteen days compared to Citrus limonum.

The pathogenicity test showed Aspergillus niger as the most virulent organism, and in culture, it was the most abundant. This suggests that $A$. niger could be the leading cause of postharvest deterioration in Citrus especially in North Central Nigeria from where all the samples were obtained. The pathogenicity test further showed that the Citrus aurantifolia plates was first to be affected by fungi and there after Citrus limonum (Plates 3-4). The results showed that previously isolated organisms at initial stage was same as the one observed after carrying out the pathogenicity test. The effective order of the pathogens present was A. niger, T.roseum, R. solani, A.ramosa, A. tenuis and $R$. stolonifer as shown in Table 1. All the fungal isolates grew very well on all the fruits of the two Citrus species. 


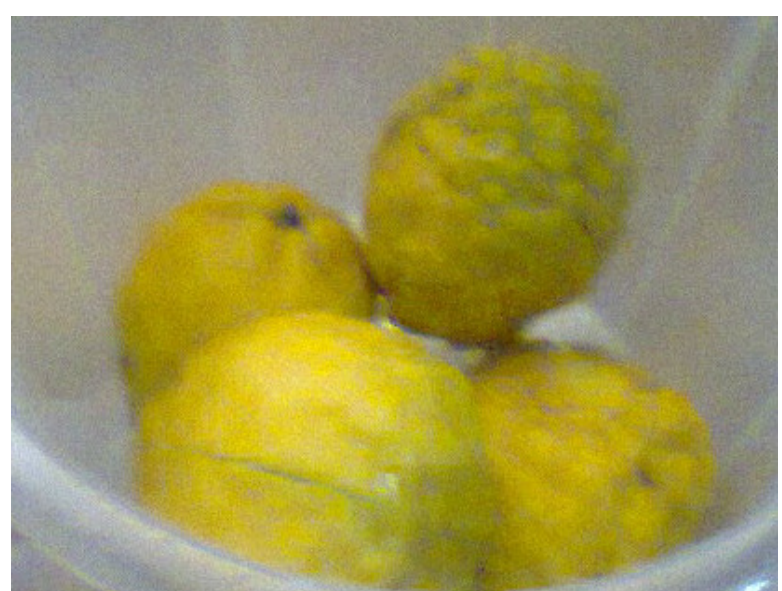

Plate 1a: Healthy lemon

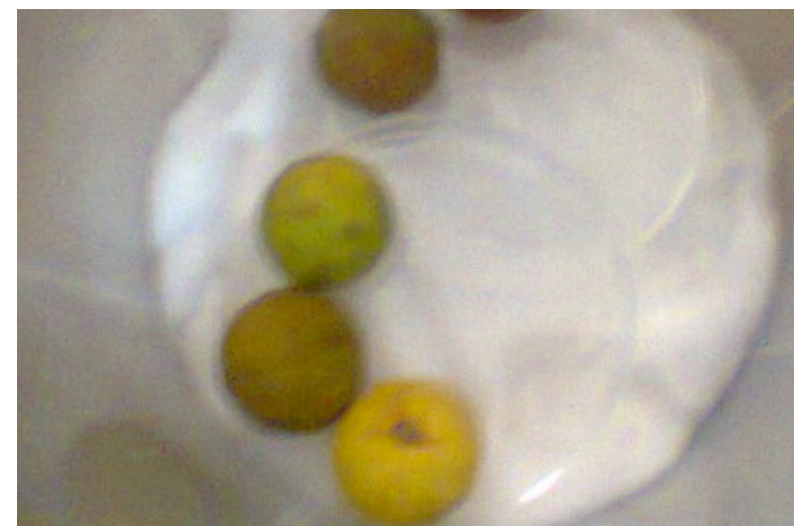

Plate 2a: Healthy lime

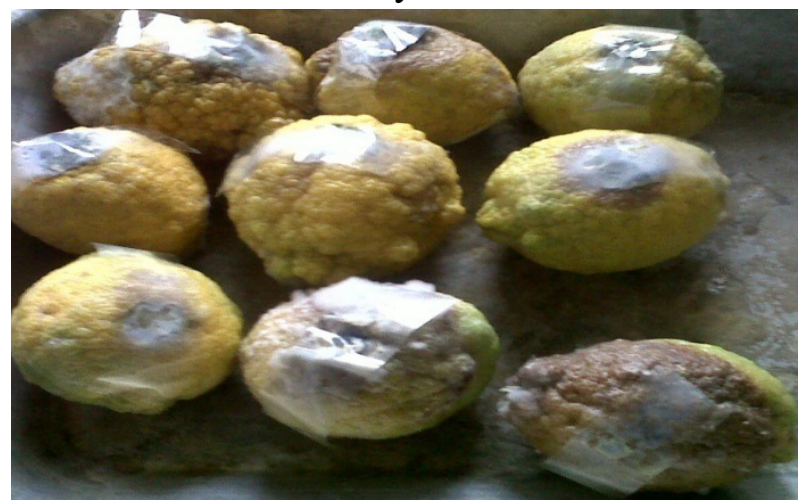

Plate 3: Pathogenicity tests on Citrus limonum

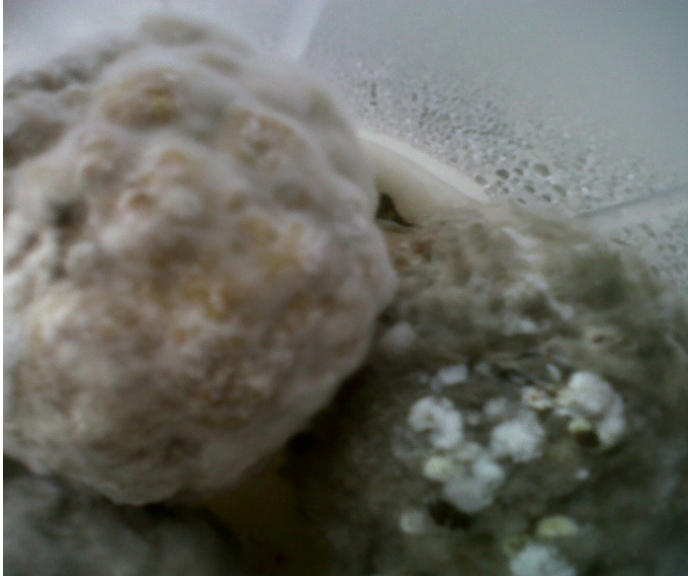

Plate 1b: Fungal growth on lemon

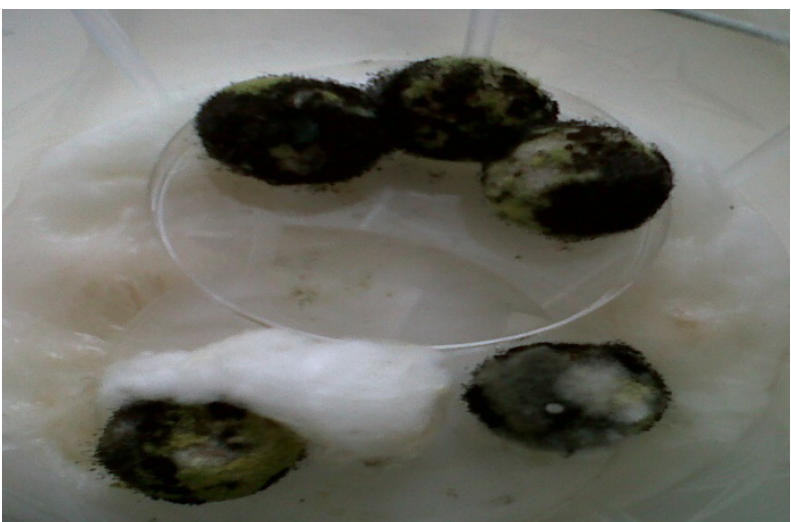

Plate 2b: Fungal growth on lime

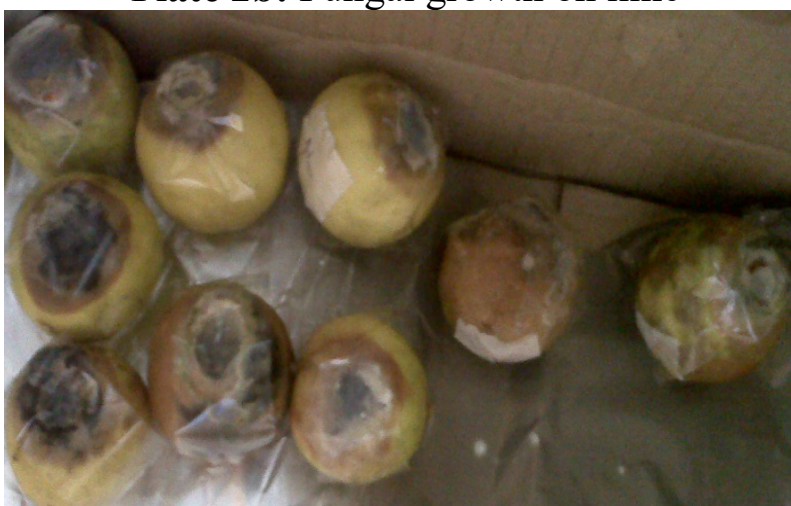

Plate 4: Pathogenicity tests on Citrus aurantifolia

Table 1: Pathogenic effects of fungal isolates on different species of Citrus fruits

\begin{tabular}{|l|l|l|l|}
\hline & Fungal Isolates & C. aurantifolia & C. limonum \\
\hline 1 & Aspergillus niger & + & + \\
\hline 2 & Trichoteciumroseum & + & + \\
\hline 3 & Rhizoctonia species & + & + \\
\hline 4 & Absidia ramosa & + & + \\
\hline 5 & Alternaria tenuis & + & + \\
\hline 6 & Rhizopus stolonifer & + & + \\
\hline
\end{tabular}

Key: $+=$ Isolates grow with a similar growth characteristic features like the original diseased samples.

\section{Antifungal potency of the extracts}

The aqueous and ethanolic extracts of the seeds of Aframomum melegueta were tested against Citrus aurantifolia and Citrus limonum pathogens to determine their antifungal activity and the 
susceptibility or resistance of the test isolates on the seed extracts. Tables 2-5 show the susceptibility and resistance of the organisms to the aqueous and ethanolic extract of both small and large Aframomum melegueta that is the sensitivity test. Zones of inhibition were observed around the disc with different radii $(\mathrm{mm})$ depending on the degree of resistance of the organism to the extract at different concentrations of 5, 10, 15, 20, 25, $30 \mathrm{mg} / \mathrm{ml}$ and Control. Table 2 shows the inhibitory effects of small seed extracts of Aframomum melegueta on the tested fungi. However, only the $20 \mathrm{mg} / \mathrm{ml}$ of the extract was able to inhibit the growth of $T$. roseum and A. ramosa.

Small and large seed extracts of Aframomum melegueta showed some inhibitory activities on the isolated fungi from the two varieties of Citrus. All the concentrations of the ethanolic extract of small A. melegueta were potent to all the organisms. The extracts were most effective on Rhizopus stolonifer which recorded the highest zone of inhibition of $34 \mathrm{~mm}, 31 \mathrm{~mm}, 29 \mathrm{~mm}, 23.5 \mathrm{~mm}, 25 \mathrm{~mm}$, $28 \mathrm{~mm}$ and $18.5 \mathrm{~mm}$ at $5,10,15,20,25,30 \mathrm{mg} / \mathrm{ml}$ and control respectively. The observed results showed that the effectiveness of the ethanolic extracts is inversely related respectively to the concentrations that is, the lower the concentration the higher the inhibitory effect (Table 2). It was further observed that the extractant (ethanol) was able to suppress the growth of all the test fungi but less than the extracts. This suggests that the extracts of small seeds of $A$. melegueta are potent in the test fungi. The $20 \%$ aqueous extract of small seed of $A$. melegueta was able to inhibit the growth of Trichothecium roseum and Absidia ramose (Table 3). The lowest zone of inhibition of all the concentrations is Rhizoctonia solani (Table 2). The concentration that had the highest zones of inhibition for the ethanolic extract is $5 \mathrm{mg} / \mathrm{ml}$ while the least was the control. The result of antifungal activity of ethanolic extract of small Aframomum melegueta against Aspergillus niger, Trichothecium roseum, Rhizoctonia species, Alternaria tenuis, Absidia ramose and Rhizopus stolonifer showed that the seed extracts possess antifungal properties and can be effective fungitoxic since they were able to inhibit the growth of wide range of fungal causative agents of the three varieties of Citrus.

The ethanolic extract of large seed of A. melegueta was able to suppress the growth of all the tested fungi (Table 4). Of all the concentration used, the most effective was on Alternaria tenuis which recorded the highest zone of inhibition of $28.5 \mathrm{~mm}, 33.5 \mathrm{~mm}, 30 \mathrm{~mm}, 23.5 \mathrm{~mm}, 23 \mathrm{~mm}, 23.5 \mathrm{~mm}$ and $17 \mathrm{~mm}$ at $5,10,15,20,25,30 \mathrm{mg} / \mathrm{ml}$ and control respectively. The aqueous extract of large seed A. melegueta was not able to suppress the growth of the test fungi except for $25 \mathrm{mg} / \mathrm{ml}$ against Absidia ramosa $(13 \mathrm{~mm})$ (Table 5). This showed that the active principles of the large seeds were not effectively extracted with aqueous. The lowest zone was recorded on Aspergillus niger (Table 5). The concentration that had the highest inhibitory effect was $10 \mathrm{mg} / \mathrm{ml}$ for Absidia ramose and Alternaria tenuis. The control has no effect on Trichothecium roseum as there was no inhibition. Result of antifungal activity of ethanolic extract of large Aframomum melegueta against Aspergillus niger, Trichothecium roseum, Rhizoctonia species, Alternaria tenuis, Absidia ramosa and Rhizopus stolonifer showed that the seed extracts possess antifungal properties and can be effective fungitoxic since they inhibited the growth of wide range of fungal causative agents of the two species of Citrus. It further shows that the ethanol is a suitable extractant of the antifungal active principles against the test fungi. On the other hand, distilled water was unable to extract the requisite active principles against fungi.

Table 2: Mean zones of inhibition of ethanol extract of the small seed of Aframomum melegueta on the tested isolates

\begin{tabular}{|l|l|l|l|l|l|l|}
\hline $\begin{array}{l}\text { Conc. } \\
(\mathrm{mg} / \mathrm{ml})\end{array}$ & $\begin{array}{l}\text { A. niger } \\
(\mathrm{mm})\end{array}$ & $\begin{array}{l}\text { Tricho } \\
(\mathrm{mm})\end{array}$ & $\begin{array}{l}\text { Rhizoc } \\
(\mathrm{mm})\end{array}$ & $\begin{array}{l}\text { Absidia } \\
(\mathrm{mm})\end{array}$ & $\begin{array}{l}\text { Alter. } \\
(\mathrm{mm})\end{array}$ & $\begin{array}{l}\text { Rhizo } \\
(\mathrm{mm})\end{array}$ \\
\hline 5 & 24 & 27 & 15.5 & 21.5 & 23.5 & 34 \\
\hline 10 & 20 & 24 & 15 & 21.5 & 27.5 & 31 \\
\hline 15 & 29 & 16 & 17.5 & 22 & 26.5 & 29 \\
\hline 20 & 29 & 18.5 & 16.5 & 24 & 25 & 23.5 \\
\hline 25 & 27.5 & 23 & 17.5 & 25 & 22.5 & 25 \\
\hline 30 & 21.5 & 22.5 & 23 & 24.5 & 25.5 & 28 \\
\hline Control & 17 & 12 & 12 & 18.5 & 19 & 18.5 \\
\hline
\end{tabular}


Table 3: Mean zones of inhibition of aqueous extract (distilled water) of the small seed of Aframomum melegueta on the tested isolates

\begin{tabular}{|l|l|l|l|l|l|l|l|}
\hline & $\begin{array}{l}\text { Conc. } \\
(\mathrm{mg} / \mathrm{ml})\end{array}$ & $\begin{array}{l}\text { A. niger } \\
(\mathrm{mm})\end{array}$ & $\begin{array}{l}\text { Tricho } \\
(\mathrm{mm})\end{array}$ & $\begin{array}{l}\text { Rhizoc } \\
(\mathrm{mm})\end{array}$ & $\begin{array}{l}\text { Absidia } \\
(\mathrm{mm})\end{array}$ & $\begin{array}{l}\text { Alter. } \\
(\mathrm{mm})\end{array}$ & $\begin{array}{l}\text { Rhizo } \\
(\mathrm{mm})\end{array}$ \\
\hline 5 & - & - & - & - & - & - \\
\hline 10 & - & - & - & - & - & - \\
\hline 15 & - & - & - & - & - & - \\
\hline 20 & - & 17 & - & 28.5 & - & - \\
\hline 25 & - & - & - & - & - & - \\
\hline 30 & & - & - & - & - & - \\
\hline
\end{tabular}

Table 4: Mean zones of inhibition of ethanol extract of the large seed of Aframomum melegueta on the tested isolates

\begin{tabular}{|l|l|l|l|l|l|l|l|}
\hline & $\begin{array}{l}\text { Conc. } \\
(\mathrm{mg} / \mathrm{ml})\end{array}$ & $\begin{array}{l}\text { A. niger } \\
(\mathrm{mm})\end{array}$ & $\begin{array}{l}\text { Tricho } \\
(\mathrm{mm})\end{array}$ & $\begin{array}{l}\text { Rhizoc } \\
(\mathrm{mm})\end{array}$ & $\begin{array}{l}\text { Absidia } \\
(\mathrm{mm})\end{array}$ & $\begin{array}{l}\text { Alter. } \\
(\mathrm{mm})\end{array}$ & $\begin{array}{l}\text { Rhizo } \\
(\mathrm{mm})\end{array}$ \\
\hline 5 & 15.5 & 12.5 & 15.5 & 24.5 & 28.5 & 22 \\
\hline & 10 & 14 & 17.5 & 15 & 30.5 & 33.5 & 19.5 \\
\hline 15 & 16.5 & 19 & 15.5 & 22 & 30 & 13.5 \\
\hline 20 & 16 & 23.5 & 15 & 19.5 & 23.5 & 24.5 \\
\hline 25 & 19.5 & 25 & 16 & 21.5 & 23 & 24.5 \\
\hline & 30 & 12.5 & 21 & 18.5 & 26 & 23.5 & 21.5 \\
\hline & Control & 9.5 & - & 10.5 & 16 & 17 & 15 \\
\hline
\end{tabular}

Table 5: Mean zones of inhibition of aqueous extract (distilled water) of the large seed of Aframomum melegueta on the tested isolates

\begin{tabular}{|l|l|l|l|l|l|l|l|}
\hline & $\begin{array}{l}\text { Conc. } \\
(\mathrm{mg} / \mathrm{ml})\end{array}$ & $\begin{array}{l}\text { A. niger } \\
(\mathrm{mm})\end{array}$ & $\begin{array}{l}\text { Tricho } \\
(\mathrm{mm})\end{array}$ & $\begin{array}{l}\text { Rhizoc } \\
(\mathrm{mm})\end{array}$ & $\begin{array}{l}\text { Absidia } \\
(\mathrm{mm})\end{array}$ & $\begin{array}{l}\text { Alter. } \\
(\mathrm{mm})\end{array}$ & $\begin{array}{l}\text { Rhizo } \\
(\mathrm{mm})\end{array}$ \\
\hline 5 & - & - & - & - & - & - \\
\hline 10 & - & - & - & - & - & - & - \\
\hline 15 & - & - & - & - & - & - \\
\hline 20 & - & - & - & 13 & - & - \\
\hline 25 & - & - & - & - & - & - \\
\hline 30 & - & - & - & - & - & - \\
\hline
\end{tabular}

\section{Note:}

A. niger $=$ Aspergillus niger

Tricho $=$ Trichothecium roseum

Rhizoc $=$ Rhizoctonia specie

Absidia $=$ Absidia ramose

Alter. = Alternaria tenuis

Rhizo $=$ Rhizopus stolonifer

The Minimum Inhibitory Concentration of the extracts was shown in Tables 6 and 7. The ethanolic extracts of small seeds of $A$. melegueta were able to suppress the mycelial growth of all the fungal isolates at $2.5,1.25,0.63 \mathrm{mg} / \mathrm{ml}$ concentrations except Absidia ramosa that was inhibited at $2.5 \mathrm{mg} / \mathrm{ml}$ but there was no growth indicating the total inhibition of the fungus. Table 7 shows the MIC of the large seeds of $A$. melegueta which indicated that at $2.5 \mathrm{mg} / \mathrm{ml}$, mycelial growth was suppress for all the fungal isolates. This observation showed that small seed extracts was more effective than the large extracts. It also indicated that there was little or no inhibition of growth at minimal concentration of the extracts. 


\section{Minimum Inhibition Concentration (MIC)}

Table 6: Minimum Inhibitory Concentration exhibited by small seeds of Aframomum melegueta extracts against some selected fungi isolates.

\begin{tabular}{|c|c|c|c|c|c|c|c|c|c|c|c|c|c|c|c|c|}
\hline \multirow{4}{*}{$\begin{array}{l}\text { Fungal } \\
\text { Isolate }\end{array}$} & \multicolumn{16}{|c|}{ Minimum Inhibitory Concentration Of Small Seed Of Alligator Pepper } \\
\hline & \multicolumn{8}{|c|}{ Aqueous Extract } & \multicolumn{8}{|c|}{ Ethanolic Extract } \\
\hline & \multicolumn{16}{|c|}{ Concentration $(\mathrm{mg} / \mathrm{ml})$} \\
\hline & 2.5 & 1.25 & 0.63 & 0.31 & 0.16 & 0.08 & 0.04 & $\mathrm{C}$ & 2.5 & 1.25 & 0.63 & 0.31 & 0.16 & 0.08 & 0.04 & $\mathrm{C}$ \\
\hline $\begin{array}{l}\text { Aspergillus } \\
\text { niger }\end{array}$ & - & - & - & - & - & - & - & - & * & $*$ & * & - & - & - & - & - \\
\hline $\begin{array}{l}\text { Trichotecium } \\
\text { roseum }\end{array}$ & - & - & - & - & - & - & - & - & * & * & * & - & - & - & - & - \\
\hline $\begin{array}{c}\text { Rhizoctonia } \\
\text { solani }\end{array}$ & - & - & - & - & - & - & - & - & * & $*$ & $*$ & - & - & - & - & - \\
\hline $\begin{array}{l}\text { Absidia } \\
\text { ramosa }\end{array}$ & - & - & - & - & - & - & - & - & + & $*$ & $*$ & - & - & - & - & - \\
\hline $\begin{array}{c}\text { Alternaria } \\
\text { tenuis }\end{array}$ & - & - & - & - & - & - & - & - & * & $*$ & $*$ & - & - & - & - & - \\
\hline $\begin{array}{l}\text { Rhizopus } \\
\text { stolonifer }\end{array}$ & - & - & - & - & - & - & - & - & * & * & $*$ & - & - & - & - & - \\
\hline
\end{tabular}

Key: $\quad+=$ No growth indicating inhibition

- = Growth indicating no inhibition

* = Reduced mycelial growth

Table 7: Minimum Inhibitory Concentration exhibited by large seeds of Aframomum melegueta extracts against some selected fungi isolates.

\begin{tabular}{|c|c|c|c|c|c|c|c|c|c|c|c|c|c|c|c|c|}
\hline \multirow{4}{*}{$\begin{array}{l}\text { Fungal } \\
\text { Isolate }\end{array}$} & \multicolumn{16}{|c|}{ Minimum Inhibitory Concentration of Large Seed of Alligator Pepper } \\
\hline & \multicolumn{8}{|c|}{ Aqueous Extract } & \multicolumn{8}{|c|}{ Ethanolic Extract } \\
\hline & \multicolumn{16}{|c|}{ Concentration $(\mathrm{mg} / \mathrm{ml})$} \\
\hline & 2.5 & 1.25 & 0.63 & 0.31 & 0.16 & 0.08 & 0.04 & $\mathrm{C}$ & 2 & 1.25 & 0.63 & 0.31 & 0.16 & 0.08 & 0.04 & $\mathrm{C}$ \\
\hline $\begin{array}{l}\text { Aspergillus } \\
\text { niger }\end{array}$ & - & - & - & - & - & - & - & - & $*$ & - & - & - & - & - & - & - \\
\hline $\begin{array}{l}\text { Trichotecium } \\
\text { roseum }\end{array}$ & - & - & - & - & - & - & - & - & * & - & - & - & - & - & - & - \\
\hline $\begin{array}{c}\text { Rhizoctonia } \\
\text { solani }\end{array}$ & - & - & - & - & - & - & - & - & * & - & - & - & - & - & - & - \\
\hline $\begin{array}{l}\text { Absidia } \\
\text { ramosa }\end{array}$ & - & - & - & - & - & - & - & -1 & * & - & - & - & - & - & - & - \\
\hline $\begin{array}{c}\text { Alternaria } \\
\text { tenuis }\end{array}$ & - & - & - & - & - & - & - & - & * & - & - & - & - & - & - & - \\
\hline $\begin{array}{l}\text { Rhizopus } \\
\text { stolonifer }\end{array}$ & - & - & - & - & - & - & - & - & * & - & - & - & - & - & - & - \\
\hline
\end{tabular}

Key: $+=$ No growth indicating inhibition

- = Growth indicating no inhibition

$*=$ Reduced mycelial growth 


\section{Discussion}

In this research, Aspergillus niger, Trichothecium roseum, Rhizoctonia species, Alternaria tenuis, Absidia ramose and Rhizopus stolonifer were isolated from two Citrus species which is similar to the findings of [23] who reported that A. niger, Alternaria species, Botryodiplodia theobromae and Colletotrichum gleosporioides were isolated from the spoilt mangoes. [24], also reported that black mold $A$. niger was caused by postharvest spoilage in sweet orange and acid lime at field. All the fungi isolated were observed to be able to reinfect those healthy Citrus within short time as shown in Plates 3 and 4, which poses a serious economic threat to sellers of Citrus fruits. However, with the help of the natural medicinal plants of Aframomum melegueta which has shown an inhibitory potential, this threat may be neutralized or reduced. The pathogenicity test showed $A$. niger as the most virulent organism, and in culture, it is the most abundant. This suggests that $A$. niger could be the leading cause of postharvest deterioration in Citrus fruits especially in North Central Nigeria from where all the samples were obtained. This is a reconfirmation of the result obtained by [25] who reported that A. niger was the most frequently occurring fungi in yam rot isolates.

For ages, Aframomum melegueta has been used in traditional medicine for the treatment of many diseases. The extracts of its seeds have been used for years in the treatment of infectious diseases as well as in treating wounds and prevention of infections. Alligator pepper extract was used by [10] in the control of Fusarium oxysporum and A. niger. [6], also showed that A. melegueta has antimicrobial and antifungal effects and also effective against schistosomes. Since ethanolic extracts of $A$. melegueta were generally more fungitoxic than water extracts, the active principles were probably extracted by ethanol than water. This agrees with [11] who observed that factors like the type of extracting solvent and age of plant could influence the active principles present in plants.

The results of the mean zones of inhibition as shown in Tables 2-5 of the seeds extract against the test organisms showed that the extracts were effective. This agrees with [22] where was reported G. kola seed extracts exhibited bactericidal effects very well when compared to standard antibiotics. The Minimum Inhibitory Concentration of the plant extract against the tested fungal isolates was also determined (Tables 6-7). The Minimum Inhibitory Concentration ranged from 0.04 to $2.5 \mathrm{mg} / \mathrm{ml}$ and it was observed that the mycelial growth were suppressed at $2.5,1.25$ and $0.63 \mathrm{mg} / \mathrm{ml}$. This is in agreement with [26] who indicate that the ethanol extract of the seed of Aframomum melegueta were more effective at low concentrations than the aqueous extract.

The antifungal effect of Aframomum melegueta could be due to the phytochemical constituents present in it. The phytochemical analysis carried out on Aframomum melegueta revealed the presence of alkaloids, tannins, saponins, steroids, cardiac glycoside, flavonoid, terpenoids and phenol [4]. The presence of these phytochemicals supports the use of this plant as antifungal and antimicrobial agent. A. melegueta can, therefore, be used as both antifungal and antimicrobial agent against the groups of Enterobacteriaceae tested [9].

The grains of Aframomum melegueta possess active ingredients that may be exploited for local development of both antimicrobials and antifungal [7]. The presence of phenolic compounds in the seeds of Aframomum melegueta showed that this plant is an antimicrobial agents and antifungal agent. This is because phenol and phenolic compounds have been extensively used in disinfections and remain the standard with which other fungicides and bacteriocides are compared [27]. Extracts from the seeds of Aframomum melegueta which have potent antiseptic or bacteriocides and fungicides properties, have therefore been used against fungi present in Citrus fruits (Lime and Lemon).

The biological function of flavonoids includes protection against allergies, inflammation, free radicals, platelet aggregation, microbes, ulcer, hepatoxins, fungi, viruses and tumors [3]. This may be the reason behind the use of the extracts of this seed in the treatment of intestinal troubles in herbal medicine [3]. The presence of phenolic compounds in the seed of Aframomum melegueta indicates that this plant might be an antimicrobial agent. Phenolic compounds as electron donors are readily oxidized to form phenolate ion or quinine, an electron acceptor. This gives rise to practical uses. Protonated phenol is used as cleaning agent. Extracts from A. melegueta, therefore, have potent antiseptic or bacteriocidal properties [3]. The use of extracts from A. melegueta in treating wounds that not only heals fast but also prevents the formation of infections was supported in the [3]. The 
presence of phenol further indicated that the seed of this plant could act as anti-inflammatory, anticlotting, antioxidant, immune enhancers and hormone modulators.

This plant also has adequate quantity of saponin. Some of the general characteristics of saponin include formation of foam in aqueous solutions, hemolytic activity, cholesterol binding properties and bitterness [3]. Apart from saponin, other metabolite constituents of Aframomum melegueta detected include the alkaloids and tannin. Alkaloids ranked the most efficient therapeutically significant plant substance. Pure isolated plant alkaloids and their synthetic derivatives are used as basic medicinal agents for their analgesic, antispasmodic and bacteriocidal effects. They exhibit marked physiological activity when administered to animals. The high tannin content could be partly responsible for the hot, bitter and pungent taste of Aframomum melegueta seed. Tannin has a stringent property; it hastens healing of wounds and inflamed mucous membrane [28]. The plants have provided a good source of anti-infective agents in the fight against microbial infections.

Aqueous and ethanolic extracts of A. melegueta similarly prevented the growth of $B$. theobromae, A. niger, A. flavus, Mucor sp., Rhizopus stolonifer, Penicillium sp. and Fusarium sp. isolated from deteriorating okro [12]. Similarly, A. melegueta seed powder was found to be effective in reducing the microbial contents of tomato ketchup and minced meat under laboratory conditions [13]. They are effective in the treatment of infectious diseases while simultaneously mitigating many of the side effects that are often associated with synthetic antimicrobials and antifungal. These findings supported that $A$. melegueta can serve as raw materials for food and pharmaceutical industries.

\section{Conclusion and Recommendation}

Since the results of this study have shown the potentials of extracts from A. melegueta seeds to control the postharvest rot of Citrus fruits, it would be necessary to use them in prolonging the shelf life of various fresh varieties of Citrus fruits. The plant is readily available, easily prepared and with little or no adverse environmental effects. Also, its use will make Citrus fruits valuable at all time thereby providing much needed economic benefits from Citrus cultivation and production. This work, therefore, provides a scientific justification for the research and is therefore recommended to be used in combating fungi associated with Citrus.

\section{References}

[1] N.N. Ntonifor et al., Antifeedant activities of crude seed extracts of tropical African species against Spodoptera littoralis (Lepidoptera: Noctuidae), Int. J. Trop. Insect Sci. 26 (2006)78-85.

[2] N.N. Ntonifor, I. Mueller-Harvey, R.H. Brown, Extracts of tropical African spices are active against Plutella xylostella, J. Food Agric. Environ. 8 (2010) 498-502.

[3] D.E. Okwu, Phytochemical and vitamin content of indigenous species of South Eastern Nigeria, Journal of Sustainable Agric. Environ. 6 (2004) 30-34.

[4] H.O. Edeoga, D.E. Okwu, B.O. Mbaeble, Phytochemical constituent of some Nigerian Medicinal Plants, African Journal of Biotechnology. 4 (2005) 685-688.

[5] A.M. Galal, Antimicrobial activity of 6-paradol and related compounds, International Journal of Pharmacognosy. 31 (1996) 37-43.

[6] M.M. Iwu, Handbook of African Medicinal Plants, Boca Raton, Florida, USA, CRC Press, 1993.

[7] J.O. Oyegade et al., Antimicrobial activity of some Nigerian medicinal Plants, screening for antibacterial activity, Journal of Bioscience Research Communication. 11 (1999) 193-197.

[8] M.K. Oladunmoye, E.O. Dada, Comparative studies on the antimicrobial activity of leafs extracts from Aframomum meleguata, Research Journal of Botany. 2(2) (2007) 95-107. 
[9] V.F. Doherty, O.O. Olaniran, U.C. Kanife, Antimicrobial activities of Aframomum melegueta (Alligator pepper), International Journal of Biology. 2(2) (2010) 126-131.

[10] R.N. Okigbo, U.O. Ogbonnaya, Antifungal effects of two tropical plant leaf extracts of (Ocimum gratissimum and Aframomium meleguata) on post-harvest yam (Dioscorea spp) rot, African Journal of Biotechnology. 5 (2006) 727-731.

[11] R.N. Okigbo, R. Putheti, C.T. Achusi, Post-harvest deterioration of cassava and its control using extracts of Azadirachta indica and Aframomum melegueta, E. J. Chem. 6 (2009) 1274-1280.

[12] B.O. Ejechi, A. Ojeata, S.B. Oyeleke, The effect of extracts of some Nigerian spices on biodeterioration of Okro (Abelmoschus (L.) Moench) by fungi, J. Phytopathol. 145 (2008) 469472.

[13] G.O. Adegoke, V.Y. Sagua, Influence of different spices on the microbial reduction and storability of laboratory-processed tomato ketchup and minced meat, Mol. Nutr. Food Res. 37 (2006) 352-355.

[14] M. Oyegun, Citrus cultivation and processing, Raw Materials Update. 3(1) (2002) 32-33.

[15] O.O. Adigun, Citrus production in Nigeria. NIHORT Occasional Paper. National Horticultural Research Institute: Ibadan, Nigeria, 1992.

[16] P. Rapisararda et al., Antioxidant effectiveness as influenced by phenolic content of fresh orange juice, J. Agric. Food Chem. 47 (1999) 4718-4723.

[17] D.E. Okwu, I.N. Emenike, Evaluation of the phyto- nutrients and vitamins content of Citrus fruits, Int. J. Mol. Med. Adv. Sci. 2 (2006) 1-6.

[18] H. Barnett, B. Hunters, Illustrated Genera of Imperfect Fungi. 4th Ed., Macmillan Incorporation, 1985.

[19] S. Madri, R.P. Singh, Management of mushroom pathogens through botanicals, Indu. Phyto Pathol. 58 (2005) 189-193.

[20] A.C. Amadioha, Evaluation of some plants against Collentrichum lindemucthi Anum in cowpea, Actophytopathological et Ethnomological Innigarica. 38 (2003) 259- 265.

[21] D.A. Akinpelu, D.O. Kolawole, Phytochemistry and antimicrobial activity of leaf extract of Piliostigma thonningii (Schum), Sci. Focus. 7 (2004) 64-70.

[22] M.F. Adegboye, D.A. Akinpelu, A.I. Okoh, The bioactive and phytochemical Properties of G. Kola (hackel) seed extract on some pathogens, African Journal of Biotechnology. 7(21) (2008) 3934-3938.

[23] V.C. Okereke, M.I. Godwin-Egein, A.E. Arinze, Assessment of postharvest rot of mango at different stages of market in Port Harcourt, Nigeria, Int. J. Curr. Res. 11 (2010) 6-10.

[24] R.V. Bali et al., Postharvest fungal spoilage in sweet orange (Citrus sinensis) and acid lime (Citrus aurentifolia Swingla) at different stages of marketing, Agricultural Science Digest. 28 (2008) 265-267.

[25] R.N. Okigbo, F.E.O. Ikediugwu, Studies on biological control of post-harvest rot of yam Dioscorea spp with Trichoderma viride, J. Phytopathol. 148 (2000) 351-355.

[26] A.C. Ogodo et al., Antimycotic and antibacterial activity of Aframomum melegueta seed extracts against bacteria and fungi species from food sources, Central African Journal of Public Healt. 3(4) (2017) 44-50.

[27] D.E. Okwu, An improving nutritive value of cassava Tapiocmeal with local spices, Journal of Nutraceutical, Functional and Medical Food. 3 (2001) 43-51.

[28] D.E. Okwu, M.E. Okwu, Chemical composition of Spondias mombia Linn plant parts, Journal of Sustain Agricultural Environment. 6 (2004) 140-147 